\title{
Interactions of $\mathrm{Cb} 1$ with Grb2 and Phosphatidylinositol $3^{\prime}$-Kinase in Activated Jurkat Cells
}

\author{
HERMAN MEISNER, BRUCE R. CONWAY, DAVID HARTLEY, AND MICHAEL P. CZECH* \\ Program in Molecular Medicine and Department of Biochemistry and Molecular Biology, \\ University of Massachusetts Medical School, Worcester, Massachusetts 01605
}

Received 28 December 1994/Returned for modification 20 February 1995/Accepted 31 March 1995

\begin{abstract}
T-cell receptor (TCR) cross-linking increases tyrosine phosphorylation of multiple proteins, only a few of which have been identified. One of the most rapidly tyrosine-phosphorylated polypeptides is the 120-kDa product of the proto-oncogene c-cbl, a cytosolic and cytoskeletal protein containing multiple proline-rich motifs that are potential binding sites for proteins containing Src homology 3 (SH3) domains. We report here that in cultured Jurkat $\mathbf{T}$ cells, Cbl is coprecipitated with antibody against the adapter protein Grb2. Upon activation of Jurkat $\mathrm{T}$ cells via the TCR-CD3 complex, we find that high-affinity binding of $\mathrm{Cbl}$ requires the $\mathrm{N}$-terminal SH3 domain of GST-Grb2 fusion protein but after cross-linking of the TCR-CD3 and CD4 receptors, Cbl binds equally to its SH2 domain. Grb2 antisera also precipitated p85 from serum-starved cells, while TCR activation increased p85 and tyrosine-phosphorylated Cbl but not Cbl protein in Grb2 immunocomplexes. Phosphatidylinositol (PI) 3-kinase activity was immunoprecipitated from serum-starved cells with Cbl and to a lesser extent with Grb2 antisera, and TCR cross-linking increased this activity severalfold. The PI 3-kinase activity associated with $\mathrm{Cbl}$ amounted to 5 to $10 \%$ of the total cellular activity that could be precipitated by $\mathrm{p85}$ antisera. The Ras exchange factor Son-of-sevenless 1 (Sos-1) was not found in anti-Cbl immunoprecipitates from activated cells, and Cbl was not detectable in anti-Sos-1 precipitates, supporting the likelihood that Sos-Grb2 and Cbl-Grb2 are present as distinct complexes. Taken together, these data suggest that Cbl function in Jurkat $T$ cells involves its constitutive association with Grb2 and its recruitment of PI 3-kinase in response to TCR activation.
\end{abstract}

A major signaling pathway involved in regulating T-lymphocyte proliferation and other functions is a PTK-dependent tyrosine phosphorylation cascade for recruiting proteins to the TCR-CD3 complex (47). The importance of this pathway is underscored by the ability of PTK inhibitors to block signal transduction, PI turnover, and $\mathrm{Ca}^{2+}$ release $(29,35)$. Although protein tyrosine phosphorylation is a critical early event that determines the selectivity of the signaling pathway, the TCR does not possess intrinsic PTK or protein tyrosine phosphatase activity (47). Receptor cross-linking increases the activity of p56 $6^{\text {lck }}$ and $\mathrm{p} 59^{\text {fyn(T)}}$, both members of the Src PTK family containing Src homology 2 (SH2) and SH3 domains (22). SH2 domains consist of segments of approximately 100 amino acids that bind particular phosphotyrosine residues, while SH3 domains are 60 -amino-acid segments that bind to proline-rich motifs having the consensus amino acid PXXP $(20,26)$. The lymphocyte isoform of Fyn binds to subunits of the TCR-CD3 complex (36). Lck, a T-cell specific PTK, binds to the CD4 coreceptor and is itself activated, an event which may coincide with tyrosine phosphorylation of the TCR $(35,41)$. Syk, a member of the Syk/ZAP 70 PTK family, is believed to be the proximal PTK that becomes phosphorylated upon TCR crosslinking $(8,15)$. Syk binds to the TCR-CD3 complex via SH2phosphotyrosine interactions at certain residues having the general sequence $\mathrm{Y}-\mathrm{X}_{2}-\mathrm{L}-\mathrm{X}_{7}-\mathrm{Y}-\mathrm{X}_{2}-\mathrm{I} / \mathrm{L}(32,37)$. Evidence suggests that both tyrosine residues in these tyrosine activation motifs must be phosphorylated to allow coupling to the $\mathrm{SH} 2$ domains of these proteins (47).

While multiple cellular proteins in T lymphocytes are phos-

* Corresponding author. Mailing address: Program in Molecular Medicine and Department of Biochemistry and Molecular Biology, University of Massachusetts Medical School, 373 Plantation St., Worcester, MA 01605. Phone: (508) 856-2254. Fax: (508) 856-1617. phorylated on tyrosine residues as a result of PTK activation (17), relatively few have as yet been identified. Phospholipase C $\gamma 1$ is tyrosine phosphorylated and activated following TCRCD3 cross-linking, resulting in the formation of diacylglycerol and inositol 1,4,5-trisphosphate, which increase the protein kinase $\mathrm{C}$ activity and intracellular $\mathrm{Ca}^{2+}$ content, respectively (46). A protein that may be associated with phospholipase $C_{\gamma} 1$ in activated $\mathrm{T}$ cells is pp36-38, which becomes tyrosine phosphorylated and binds to the $\mathrm{SH} 2$ domain of Grb2 after activation (39). Grb2, a protein composed of two SH3 domains and one $\mathrm{SH} 2$ domain, links receptor/nonreceptor PTK to $\mathrm{p} 21^{\text {ras }}$ pathways by complexing with the guanine nucleotide exchange proteins Sos- 1 and Sos-2. A fraction of the cellular pool of Sos is bound stably to Grb2 by interaction with the N-terminal SH3 domain $(10,34)$. Shc is another widely expressed SH2-containing protein that becomes tyrosine phosphorylated in response to a variety of growth factors and associates with the $\mathrm{SH} 2$ domain of Grb2, which in turn binds Sos-1 (27). Shc has been reported to complex with Grb2-Sos and to the phosphorylated zeta-C motif after activation (29), although the stoichiometry of Shc tyrosine phosphorylation and association with Grb2 is low in T lymphocytes (39). Another possible substrate for Grb2 is a 75-kDa protein that becomes tyrosine phosphorylated after receptor cross-linking, and binds in vitro to the $\mathrm{SH} 3$ domains of a Grb2 fusion protein (31).

A major phosphotyrosine-containing protein band of 120 $\mathrm{kDa}$ that binds to SH3 and SH2 domains of Lck, Fyn, Src, p85, and Grb2 in vitro has been observed by several groups, including our laboratory, studying T-cell activation $(21,25,30)$. While the present work was in progress, the $120-\mathrm{kDa}$ tyrosinephosphorylated protein that binds to Grb2 SH3 domains in vitro in $\mathrm{T}$ cells was identified as the product of the protooncogene c-cbl (9). Cbl is a 906-amino-acid protein that is distributed in cytosol and cytoskeletal compartments and con- 
tains 17 proline-rich motifs in the $\mathrm{C}$ terminus with potential to bind SH3 domains (6). The viral oncogene product, $\mathrm{v}-\mathrm{Cbl}$, is a severely truncated C-terminal form, localized in both the cytoplasm and the nucleus, where it can bind to DNA. This truncated form of $\mathrm{Cbl}$ may therefore act as a transcription factor. Although a truncated nuclear protein encoded by c-cbl has been proposed to exist (6), no such protein has been identified in the nucleus as yet.

The fact that $\mathrm{Cbl}$ associates with GST-Grb2 in cell-free systems (8) suggests the possibility that it is involved in the function of Sos or other proteins that also interact with Grb2. The aim of the present studies was to evaluate the mechanism of Grb2 binding to $\mathrm{Cbl}$ in activated Jurkat T cells as well as its potential relationship to the $\mathrm{p} 21^{\text {ras }}$ and PI 3-kinase pathways. We report here that $\mathrm{Cb}$ is indeed associated with both Grb2 and p85 in intact Jurkat cells and that immunocomplexes of Cbl contain PI 3-kinase activity that is activated three- to fourfold upon TCR cross-linking. Furthermore, our data indicate that the Grb2 bound to $\mathrm{Cbl}$ in intact cells is not available to associate with Sos-1.

\section{MATERIALS AND METHODS}

Abbreviations used in this paper. BSA, bovine serum albumin; GST, glutathione $S$-transferase; HEPES, $N$-2-hydroxyethylpiperazine- $N N^{\prime}$-2-ethanesulfonic acid; HRP, horseradish peroxidase; Ig, immunoglobulin; IRS, insulin receptor substrate; MAb, monoclonal antibody; PI, phosphatidylinositol; PTK, protein tyrosine kinase; SDS-PAGE, sodium dodecyl sulfate-polyacrylamide gel electrophoresis; SH, Src homology; Sos, son of Sevenless; TCR, T-cell receptor.

Antibodies and reagents. A fusion protein, GST-p85SH2, comprising both $\mathrm{SH} 2$ domains of $\mathrm{p} 85$ from nucleotides 986 to 2313 , was made by PCR amplification of human $\mathrm{p} 85$ alpha cDNA with the primers 5'-CTACTGGATCCAA CAACGGTATG-3' (sense) and 5'-CAGCGGAATTCACAGATCAGACTG-3' (antisense) followed by cloning into pGEX2T. The correct sequence was verified by double-strand sequencing. After transfection into Escherichia coli XA90, the fusion protein was affinity purified on glutathione-agarose beads (Sigma) from the Triton X-100-soluble fraction after induction with $\beta$-D-thiogalactopyranoside. A Sos-1 C-terminal polyclonal antibody was made by PCR amplification of mSos-1 (amino acids 1230 to 1333) with the primers 5'-CCATTACGGATC CAACCTCCTCC-3' (sense) and 5' -GAAGAATTCGCATTCTCCAGC-3' (antisense) and ligated into pGEX3X, and the expressed fusion protein was injected into rabbits. The anti-Grb2 polyclonal antibody was made by immunizing rabbits with a full-length GST-Grb2 fusion protein. Human GST-Grb2, GST-P49L Grb2 (SH3 mutant), and GST-R86K Grb2 (SH2 mutant) were gifts from J. Schlessinger. Polyclonal Cbl antibody was purchased from Santa Cruz Inc., and p85 antibody was purchased from UBI, Lake Placid, N.Y. The Grb2 MAb was from Transduction Labs, and antiphosphotyrosine MAb 4G10 was from UBI. HRPconjugated rabbit anti-sheep IgG-HRP was from Zymed; rabbit anti-mouse IgG-HRP and protein A-HRP were from Amersham. HRP was detected by chemiluminescence (Boehringer Mannheim). OKT3 and OKT4 MAbs were purified from cell culture supernatants by passage over protein G-sepharose in a high-salt buffer (13)

Cell culture. The Jurkat cell line E6-1, obtained from the American Type Culture Collection, was grown in RPMI 1640 supplemented with $7 \%$ fetal calf serum (Gibco), 2 mM glutamine, $10 \mathrm{mM}$ HEPES (pH 7.4), $50 \mu \mathrm{M}$ 2-mercaptoethanol, and penicillin/streptomycin. Hybridoma cells producing anti-CD3€ MAb OKT3 and anti-CD4 MAb OKT4 were obtained from the American Type Culture Collection and grown in Dulbecco's modified Eagle's medium plus 20\% fetal calf serum.

Cell stimulation and preparation of cell lysates. Cells were grown to a density of $10^{6} / \mathrm{ml}$, centrifuged, and serum starved in serum-free RPMI 1640 for $4 \mathrm{~h}$. Cells were resuspended at $5 \times 10^{7} / \mathrm{ml}$ in serum-free RPMI 1640 at $4^{\circ} \mathrm{C}$. CD3 and CD4 receptors were bound to $10 \mu \mathrm{g}$ of OKT3 and OKT4 per $\mathrm{ml}$ at $4^{\circ} \mathrm{C}$ for $10 \mathrm{~min}$; this was followed by cross-linking with a fourfold excess of anti-mouse IgG (Cappel) for $10 \mathrm{~min}$ at $4^{\circ} \mathrm{C}$. Cells were heated at $37^{\circ} \mathrm{C}$ for $2 \mathrm{~min}$; washed immediately in cold phosphate-buffered saline containing $0.5 \mathrm{mM} \mathrm{Na}_{3} \mathrm{VO}_{4}, 5 \mathrm{mM}$ EDTA, and $10 \mathrm{mM} \mathrm{NaF}$; and lysed with $1 \%$ Nonidet P-40 in buffer A (10 mM Tris [pH 7.5], $1 \mathrm{mM}$ EDTA, $150 \mathrm{mM} \mathrm{NaCl}, 1 \mathrm{mM}$ vanadate, $0.1 \mathrm{mM}$ phenylmethylsulfonyl fluoride, and $25 \mu \mathrm{g}$ of aprotinin per $\mathrm{ml}$ ) for $15 \mathrm{~min}$ at $4^{\circ} \mathrm{C}$. Nuclei were removed by centrifugation at $12,000 \times g$ for $4 \mathrm{~min}$. Cells activated with OKT3 received only OKT3 $(10 \mu \mathrm{g} / \mathrm{ml})$ and nonstimulated cells were incubated with anti-IgG (80 $\mu \mathrm{g} / \mathrm{ml}$ ) before being heated at $37^{\circ} \mathrm{C}$ for $2 \mathrm{~min}$.

Immunoprecipitation and blotting. Lysates were cleared with 2 to $5 \mu \mathrm{l}$ of preimmune serum per $10^{7}$ cell equivalents and bound to protein A-Sepharose for $15 \mathrm{~min}$ at $4^{\circ} \mathrm{C}$. After centrifugation, supernatants were mixed with 2 to $5 \mu \mathrm{l}$ of primary antibody per $10^{7}$ cells plus protein A- or G-Sepharose for $1 \mathrm{~h}$ at $4^{\circ} \mathrm{C}$. Beads were washed successively with $0.2 \%$ Nonidet P-40 in buffer A, $0.5 \mathrm{M} \mathrm{NaCl}$
A

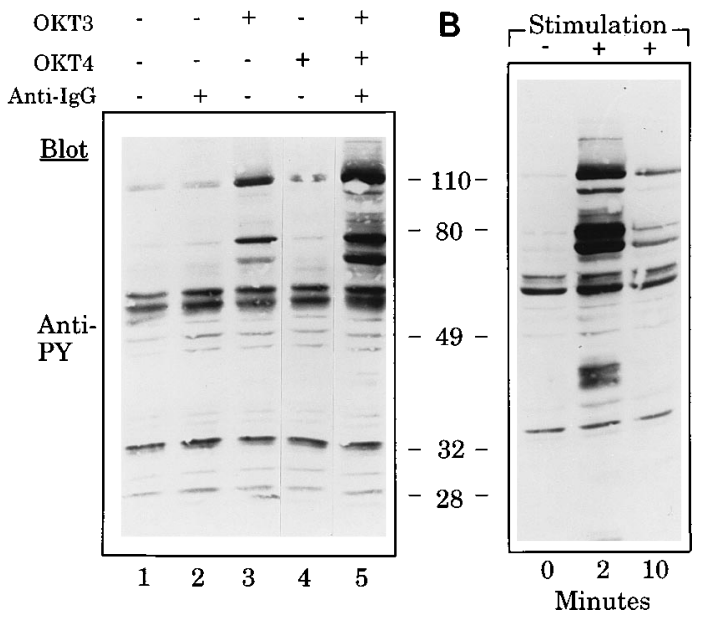

FIG. 1. Tyrosine phosphorylation in Jurkat T cells activated via the CD3 and CD4 receptors. Cells were serum starved in RPMI 1640 for $4 \mathrm{~h}$ and resuspended in serum-free RPMI 1640 at $5 \times 10^{7}$ cell equivalents per ml. (A) Cells were activated as indicated with $10 \mu \mathrm{g}$ each of OKT3 and OKT4 and $80 \mu \mathrm{g}$ of anti-mouse IgG at $37^{\circ} \mathrm{C}$ for $2 \mathrm{~min}$. (B) Cells were activated with OKT3-OKT4anti-IgG for the times indicated, washed in PBS, and lysed in 1\% Nonidet P-40. Approximately $5 \times 10^{5}$ cell equivalents of total-cell lysate were loaded per lane, electrophoresed, and, after transfer to nitrocellulose, blotted with antiphosphotyrosine (anti-PY) antibody 4G10. Detection was performed by chemiluminescence.

in buffer A, and $10 \mathrm{mM}$ Tris (pH 7.5) and solubilized by being boiled for $5 \mathrm{~min}$ in SDS-PAGE sample buffer. Proteins were separated in 7 or $12 \%$ SDS-PAGE minigels (Bio-Rad), transferred onto nitrocellulose filters (Schleicher \& Schuell, Keene, N.H.) by electroblotting for $3 \mathrm{~h}$ at $300 \mathrm{~mA}$, and blocked in either $1 \%$ BSA (antiphosphotyrosine blots) or 5\% dry milk, plus buffer B (10 mM Tris [pH 7.5] $100 \mathrm{mM} \mathrm{NaCl}, 0.1 \%$ Tween 20 ). All primary antibodies were added in buffer B at $1 \mu \mathrm{g} / \mathrm{ml}$, except 4G10, which was used at $0.25 \mu \mathrm{g} / \mathrm{ml}$, for 1 to $2 \mathrm{~h}$. Secondary antibodies were added at 0.02 to $0.1 \mu \mathrm{g} / \mathrm{ml}$, and the filters were washed extensively and visualized by chemiluminescence.

Far Western blots. Nitrocellulose filters containing resolved proteins were denatured in buffer $\mathrm{C}(25 \mathrm{mM} \mathrm{NaCl}, 5 \mathrm{mM} \mathrm{MgCl}, 25 \mathrm{mM}$ HEPES [pH 7.9], 1 $\mathrm{mM}$ dithiothreitol) plus $6 \mathrm{M}$ guanidine for $15 \mathrm{~min}$ at $4^{\circ} \mathrm{C}$. Proteins were gradually renatured in buffer $\mathrm{C}$, blocked in $1 \% \mathrm{BSA}$, and hybridized at $4^{\circ} \mathrm{C}$ overnight with GST-Grb2 fusion protein $(1 \mu \mathrm{g} / \mathrm{ml})$. Detection was performed with anti-GST antibody followed by chemiluminescence.

Binding with fusion proteins. Lysates $\left(10^{7}\right.$ cell equivalents) were incubated with $10 \mu \mathrm{g}$ of GST fusion protein (quantitated by Coomassie blue staining with a range of BSA standards) plus glutathione-agarose as carrier for $1 \mathrm{~h}$ at $4^{\circ} \mathrm{C}$. The beads were washed as described above.

PI 3-kinase activity assay. PI 3-kinase activity was measured as described previously (4) with immunoprecipitates of lysates from $10^{7}$ cell equivalents, 1 $\mathrm{mM}$ plant PI plus phosphatidylserine as the substrate, and $10 \mu \mathrm{M}\left[{ }^{32} \mathrm{P}\right] \mathrm{ATP}(25$ $\mathrm{Ci} / \mathrm{mmol}$ ). The labeled lipid products were separated by thin-layer chromatography on silica gel plates and quantitated by exposure on a Betascope (Betagen).

\section{RESULTS}

Protein tyrosine phosphorylation is an early event in Tlymphocyte signaling and can be induced to different degrees by cross-linking of the CD4 and CD3-TCR receptors (17). In Fig. 1, serum-starved Jurkat cells were activated with the CD4 antibody OKT4 or the CD3 antibody OKT3 or by adding both antibodies and cross-linking them with anti-IgG. Tyrosine phosphorylation in Jurkat T cells was maximal when the OKT3 and OKT4 antibodies were cross-linked with anti-IgG (lane 5) and weaker when only the CD3 receptor was activated (lane 3). Cross-linking of OKT3 and OKT4 antibodies on Jurkat cells initiated a pronounced phosphorylation of multiple proteins, including a prominent band at $120 \mathrm{kDa}$, within $2 \mathrm{~min}$. Stimulation was transient and diminished considerably by $10 \mathrm{~min}$.

Several reports have noted that various $\mathrm{SH} 2$ domains bind to a 115 - to $120-\mathrm{kDa}$ protein in hematopoietic cells. For example, a $120-\mathrm{kDa}$ protein complexes in vitro with SH2 domains of Fyn 


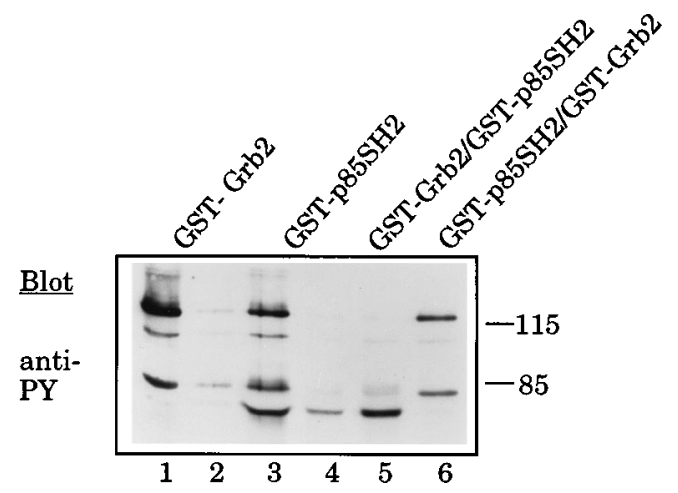

FIG. 2. Grb2-GST and p85-GST fusion proteins bind to the same p120 tyrosine-phosphorylated protein in activated Jurkat T cells. Lysates from $10^{7}$ cells activated by cross-linking with OKT3 and OKT4 were incubated at $4^{\circ} \mathrm{C}$ with $10 \mu \mathrm{g}$ of GST-Grb2 (lane 1) or $10 \mu \mathrm{g}$ of GST-p85SH2 (lane 3) for $1 \mathrm{~h}$. After centrifugation, supernatants from the GST-Grb2 binding were mixed again with $10 \mu \mathrm{g}$ of either GST-Grb2 (lane 2) or GST-p85SH2 (lane 5); the GST-p85SH2 supernatants were mixed with GST-p85SH2 (lane 4) or GST-Grb2 (lane 6) for an additional $1 \mathrm{~h}$. All pellets were washed and resuspended in SDS sample buffer. Samples were electrophoresed in $7 \%$ acrylamide, transferred to nitrocellulose, blotted with the antiphosphotyrosine (anti-PY) antibody 4G10, and detected by chemiluminescence.

and Lyn after activation of $\mathrm{T}$ cells (30), and a 116-kDa tyrosine-phosphorylated protein becomes tightly coupled to p85/PI 3-kinase after anti-IgG cross-linking of the monocytic cell line U937 (24). We therefore examined whether a GST$\mathrm{Grb} 2$ fusion protein or one containing both $\mathrm{SH} 2$ domains of p85 bind to a common $120-\mathrm{kDa}$ protein. Figure 2 shows that both fusion proteins bound a phosphotyrosine protein of 120 $\mathrm{kDa}$ from lysates of activated cells (lanes 1 to 4 ). When GSTp85SH2 was added to supernatants from GST-Grb2-depleted lysates (lane 5), no 120-kDa polypeptide was adsorbed. However, GST-Grb2 was able to bind a population of tyrosinephosphorylated p120 that was not reactive with GST-p85SH2 (lane 6). Thus, both proteins were bound to the same p120 polypeptide, although the GST-Grb2 fusion protein recognized in addition a subfraction of tyrosine-phosphorylated p120 that was not bound by GST-p85SH2.

Donovan et al. (9) have reported that the 120-kDa tyrosinephosphorylated protein that binds to a GST-Grb2 fusion protein in activated Jurkat cells is the product of the proto-oncogene c-cbl. The p120 protein identified in our studies (Fig. 1 and 2) was also found to be $\mathrm{Cbl}$ (Fig. 3). Lysates from resting and stimulated Jurkat cells were immunoprecipitated with $\mathrm{Cbl}$, Grb2, or p85 antisera and blotted against Cbl, 4G10, or p85 antisera. All antisera precipitated a protein of the same size that was recognized by Cbl antiserum but was not present in precipitates of nonimmune rabbit serum. The amount of $\mathrm{Cbl}$ found in Grb2 immunoprecipitates was not affected by activation (lanes 6 and 7), whereas the amount bound to p85 was increased (lanes 4 and 5). The antiphosphotyrosine blot reveals that receptor cross-linking increased the amount of tyrosinephosphorylated $\mathrm{Cbl}$ immunoprecipitated with anti-p85 (lanes 4 and 5) and anti-Grb2 (lanes 6 and 7). Activation of Jurkat cells resulted in a noticeable shift in the intensity of a doublet band in anti-Cbl blots of p85 and Grb2 immunoprecipitates (lanes 4 to 7) and may correspond to two populations of differentially phosphorylated $\mathrm{Cbl}$. The bottom panel shows that $\mathrm{Cbl}$ and Grb2 antisera coprecipitate $\mathrm{p} 85$ and that activation increases the amount bound to both of these proteins (lanes 6 to 9). Thus, Grb2 and p85 are bound in vivo to $\mathrm{Cbl}$, and activation results in an increase in the amount of p85 in this complex.

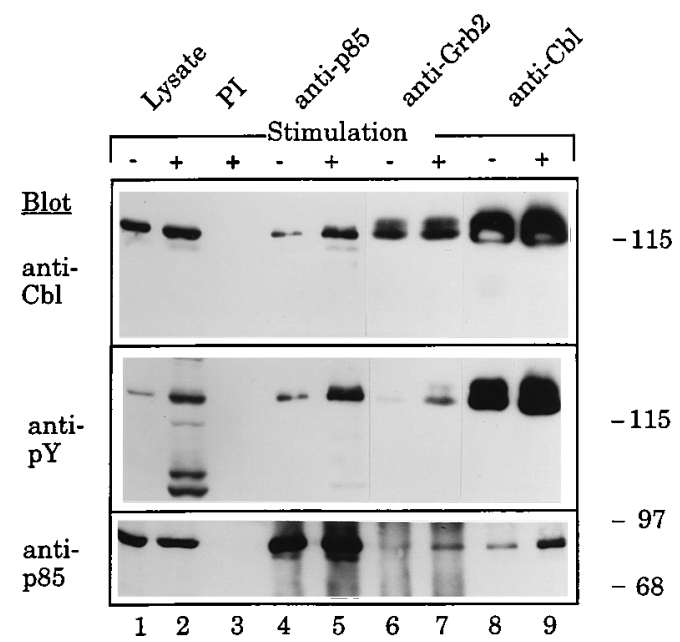

FIG. 3. The tyrosine-phosphorylated p120 protein in Jurkat cells that immunoprecipitates with Grb2 and p85 is Cbl. Lysates from unstimulated and fully activated cells $\left(10^{7}\right.$ cell equivalents $)$ were precleared with normal rabbit serumprotein A Sepharose before immunoprecipitation with normal sera (lane 3), anti-p85 (lanes 4 and 5), anti-Grb2 (lanes 6 and 7); or anti-Cbl (lanes 8 and 9). Lanes 1 and 2 are total-cell lysates of $5 \times 10^{5}$ cells. Following electrophoresis and transfer to nitrocellulose, samples were probed with $\mathrm{Cbl}$ (top), the antiphosphotyrosine (anti-pY) antibody 4G10 (middle), or p85 (bottom) antiserum and visualized by chemiluminescence.

The role of Src family SH3 domains in binding a tyrosinephosphorylated $120-\mathrm{kDa}$ protein in activated $\mathrm{T}$ cells has been well documented $(25,30)$, and this protein has been identified recently as $\mathrm{Cbl}(9)$. In the present study, the affinity of p120/Cbl in Jurkat cells for the $\mathrm{SH} 2$ and $\mathrm{SH} 3$ domains of Grb2 was tested by binding a native GST-Grb2 fusion protein or GSTGrb2 proteins with an inactivating mutation in the N-terminal SH3-binding domain (P49L) or SH2-binding domain (R86K). Figure 4 (top) shows that after fully activating Jurkat cells by cross-linking the CD3 and CD4 receptors, a tyrosine-phosphorylated $120-\mathrm{kDa}$ protein bound with equal affinity to GSTGrb2, GST-P49L, and GST-R86K between 0.2 and $10 \mu \mathrm{g}$ of the GST fusion proteins. Blotting the fusion protein precipitates for $\mathrm{Cbl}$ yielded identical results, indicating that the stoichiometries of tyrosine phosphorylation of the $120-\mathrm{kDa}$ protein recognized by the native and mutant Grb2 fusion proteins are similar and that this protein is Cbl. In experiments not illustrated, tyrosine-phosphorylated pp36-38 (39) did not bind to GST-R86K (mutated SH2) and the Ras exchange factor mSos-1 was not complexed to GST-P49L (mutated N-SH3), confirming that both point mutations were functionally unable to react with their known substrates in activated cells $(10,34)$.

Previous results (21) showed that in OKT3-stimulated cells, GST-P49L bound less Cbl than did the native GST-Grb2 protein. Figure 4 (bottom two panels) confirms this result by showing the dose-response relationship of GST-Grb2 fusion protein binding to $\mathrm{Cbl}$, using lysates of Jurkat cells that were activated with $10 \mu \mathrm{g}$ of OKT3 only. It is evident that although wild-type GST-Grb2 and GST-R86K showed similar apparent high affinities and capacities for binding $\mathrm{Cbl}$, the amount of $\mathrm{Cbl}$ bound by the P49L mutant was greatly reduced. Significant binding of Cbl to GST-P49L was seen only above $2.5 \mu \mathrm{g}$ of protein. Thus, in the fully activated state, $\mathrm{Cbl}$ can bind with high affinity to either the $\mathrm{SH} 2$ or SH3 domains of Grb2; however, in the partially tyrosine-phosphorylated state (OKT3 cross-linking only) or in nonactivated cells, the N-terminal SH3 domain is necessary to bind similar amounts of Cbl. 


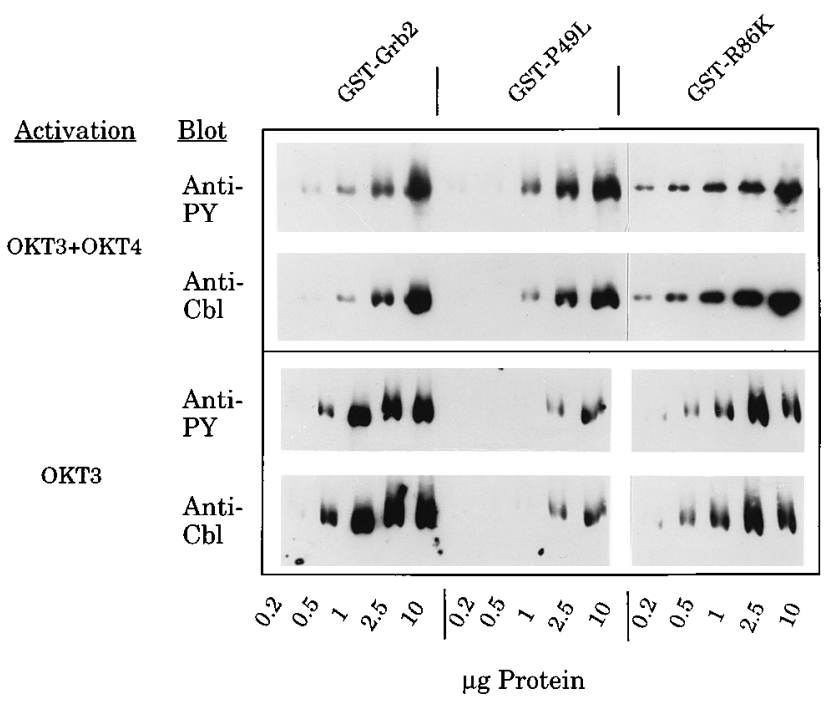

FIG. 4. The affinity of $\mathrm{Cbl}$ for Grb2 $\mathrm{SH} 2$ and $\mathrm{SH} 3$ domains is dependent upon the extent of CD3 and CD4 receptor cross-linking in Jurkat cells. (Top) Lysates from $10^{7}$ cells activated with OKT3-OKT4-anti-IgG were mixed for $1 \mathrm{~h}$ with the indicated amount of GST-Grb2, GST-P49L (-SH3), or GST-R86K (-SH2), plus glutathione-agarose as required, washed, and solubilized in SDS sample buffer. (Bottom) Cells were activated with $10 \mu \mathrm{g}$ of OKT3 per ml for 2 min, and lysates were mixed with the GST-Grb2 proteins as indicated. After electrophoresis and transfer to nitrocellulose, membranes were blotted with the antiphosphotyrosine (anti-PY) antibody 4G10 or anti-Cbl and detected by chemiluminescence. The concentrations of the GST fusion proteins were estimated by comparison with Coomassie blue-stained BSA standards.

It is likely that Grb2 and $\mathrm{Cbl}$ form stable complexes in intact cells through binding the N-terminal SH3 domain of Grb2 to proline-rich motifs in the $\mathrm{C}$ terminus of $\mathrm{Cbl}(9,33)$. In view of the apparent high affinity of the $\mathrm{Grb} 2 \mathrm{SH} 2$ domain for $\mathrm{Cb}$ (Fig. 4, top panels), we examined whether Grb2 SH2 was bound directly to $\mathrm{Cbl}$ by boiling cell lysates in $0.5 \%$ SDS to dissociate preformed complexes, diluting them 10 -fold in $0.2 \%$ Nonidet P-40, and then incubating them with $10 \mu \mathrm{g}$ of GSTGrb2 fusion proteins. In Fig. 5, the antiphosphotyrosine blot of adsorbed proteins shows that boiling samples in SDS had no effect on the binding of Cbl to full-length GST-Grb2 (lanes 2, 3,8 , and 9) or to the SH2 mutant GST-R86K (lanes 6, 7, 12,

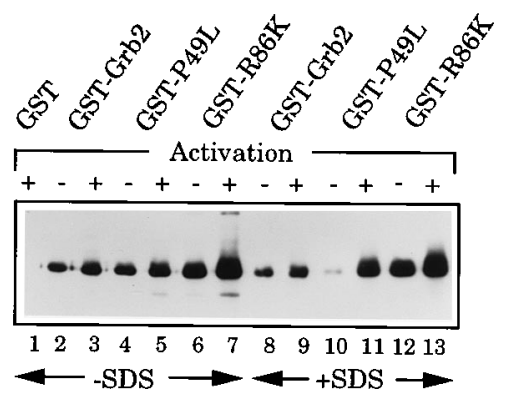

FIG. 5. Grb2 SH2 and SH3 domains bind directly to $\mathrm{Cbl}$ in activated Jurkat cells. Lysates from unstimulated and fully activated cells $\left(10^{7}\right.$ cell equivalents) were boiled for $5 \mathrm{~min}$ in $0.5 \%$ SDS (lanes 8 to 13 ) and cooled to $4^{\circ} \mathrm{C}$. All lysates were diluted 10 -fold in $1 \%$ Nonidet P-40 lysis buffer, mixed with $10 \mu \mathrm{g}$ of protein for $1 \mathrm{~h}$, and washed, and SDS sample buffer was added. Following electrophoresis and transfer to nitrocellulose, samples were probed with 4G10 MAb and visualized by chemiluminescence.

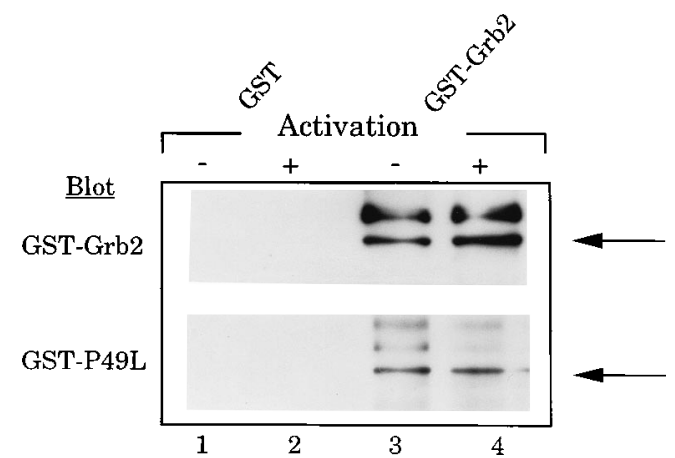

FIG. 6. The GST-Grb2 SH3 mutant binds directly to $\mathrm{Cbl}$ in a far Western blot. Lysates from unstimulated and fully activated cells $\left(10^{7}\right.$ cell equivalents) were bound to $10 \mu \mathrm{g}$ of GST or GST-Grb2. After electrophoresis and transfer to nitrocellulose, samples were subjected to denaturation-renaturation, probed with GST-Grb2 or GST-P49L $(1 \mu \mathrm{g} / \mathrm{ml})$ followed by anti-GST antibody, and visualized by chemiluminescence. The band corresponding to $\mathrm{Cbl}$ (arrow) was detected by stripping the filter and reprobing with the anti-Cbl antibody.

and 13). Boiling also had no effect on the binding of Cbl to the SH3 mutant GST-P49L after Jurkat cell activation (lanes 5 and 11) but reduced the association in lysates from serum-starved cells (lanes 3 and 10). These data are consistent with the possibility that the $\mathrm{SH} 2$ domain of Grb2 binds directly to $\mathrm{Cbl}$, at least in activated cells. This conclusion is strengthened by the data in Fig. 6, which is a far Western blot of proteins in cell lysates bound to GST or GST-Grb2. After electrophoresis and transfer of resolved proteins to a nitrocellulose filter and renaturation, the membrane was probed with either Grb2 (Fig. 6, top) or the P49L mutant protein (Fig. 6, bottom). Both proteins were bound to the same $120-\mathrm{kDa}$ band that was also recognized by $\mathrm{Cbl}$ antiserum (arrow). The identity of the more slowly migrating band recognized by GST-Grb2 (top, lanes 3 and 4) is unknown, but it is likely to be a different Grb2-SH3binding protein.

Ward et al. (45) have observed an increase in cellular $3^{\prime}$ phosphorylated polyphosphoinositides following TCR crosslinking. The binding of $\mathrm{p} 85$ to $\mathrm{Cbl}$ that we have observed (Fig. 3 ) raised the possibility that $\mathrm{CD} 3-\mathrm{CD} 4$ receptor ligation is accompanied by an increase in PI 3-kinase activity in the Cblp85 complex. PI 3-kinase activity was measured by immunoprecipitating lysates of resting and TCR-cross-linked Jurkat cells with antisera to p85, Grb2, and $\mathrm{Cbl}$ and resolving the $\left[\gamma^{-32} \mathrm{P}\right]$ ATP incorporated into PI 3 '-phosphate by thin-layer chromatography (Table 1; Fig. 7). After TCR cross-linking, total PI 3-kinase activity immunoprecipitated with p85 antisera increased about twofold, but it rose fourfold in $\mathrm{Cbl}$ immunocomplexes and to a similar extent in Grb2 immunoprecipitates.

TABLE 1. TCR cross-linking increases PI 3-kinase activity associated with $\mathrm{Cbl}^{a}$

\begin{tabular}{lcc}
\hline \multirow{2}{*}{ Antiserum } & \multicolumn{2}{c}{ PI 3-kinase activity $(\%)^{b}$} \\
\cline { 2 - 3 } & Unstimulated & OKT3-OKT4 \\
\hline $\mathrm{p} 85$ & 100 & $192 \pm 11$ \\
$\mathrm{Cb} 1$ & $4.5 \pm 0.5$ & $19.5 \pm 6.2$ \\
Grb2 & $0.46 \pm 0.11$ & $1.40 \pm 0.46$
\end{tabular}

${ }^{a}$ For experimental details, see the text and the legend to Fig. 7.

${ }^{b}$ Sample radioactivity was quantified by exposure on a Betascope and is expressed as the percentage of PI 3-phosphate in p85 immunoprecipitates, which averaged 1,090 cpm. Data are the mean \pm standard deviation from three experiments performed in duplicate. 


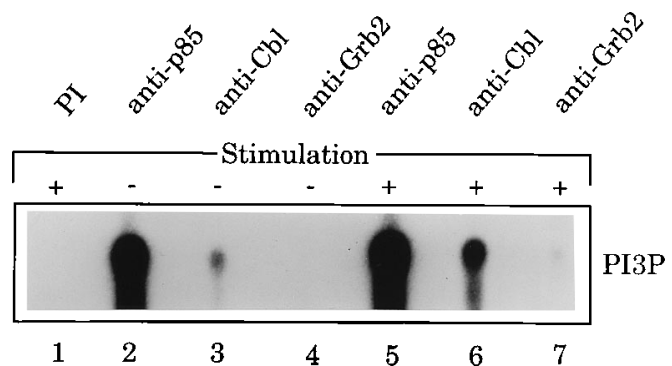

FIG. 7. TCR cross-linking increases PI 3-kinase activity associated with $\mathrm{Cbl}$. Serum-starved cells were activated for 2 min by cross-linking with OKT3 and OKT4 antisera. Lysates from $10^{7}$ cell equivalents of unstimulated (lanes 2 to 4 ) and fully activated cells (lanes 1 and 5 to 7 ) were mixed for $1 \mathrm{~h}$ with $1 \mu \mathrm{g}$ of antiserum and, after being washed, incubated with $\left[\gamma_{-}{ }^{32} \mathrm{P}\right]$ ATP plus $1 \mathrm{mM}$ PIphosphatidylserine as described in Materials and Methods. Samples were extracted with chloroform-methanol, and the PI 3-phosphate (PI3P) was resolved by thin-layer chromatography and visualized by autoradiography. Sample radioactivity was quantified by exposure on a Betascope. A representative autoradiogram is shown.

The small amount of PI 3-kinase activity complexed to Grb2 probably represents an underestimate, since our anti-Grb2 antibody does not immunoprecipitate all of the cellular Grb2. However, the amount of $\mathrm{Cbl}$ and $\mathrm{p} 85$ antisera used for the immunoprecipitations depleted $\mathrm{Cbl}$ and $\mathrm{p} 85$ from cell lysates virtually completely, as judged by analysis of postantibody supernatants by SDS-PAGE followed by Western blotting (data not shown). Therefore, the data in Table 1 and Fig. 7 suggest that 5 to $10 \%$ of the total PI 3-kinase activity in Jurkat cells is associated with $\mathrm{Cbl}$ in a TCR activation-dependent manner.

The evidence presented in Fig. 5 and 6 suggesting that the Grb2 SH2 domain binds directly to $\mathrm{Cbl}$ raised the possibility that Sos, which binds predominantly to the N-terminal SH3 domain of Grb2, forms a trimeric complex with Cbl. To examine this, T-cell lysates were immunoprecipitated with mSos-1 and $\mathrm{Cbl}$ antisera, and after electrophoresis, the nitrocellulose membrane was probed for the presence of Cbl, Sos-1, or Grb2 (Fig. 8). Although Sos-1 and Cbl antisera recognized their respective epitopes at 170 and $120 \mathrm{kDa}$ in total-cell lysates and immunoprecipitates, no Sos- 1 was found in $\mathrm{Cbl}$ precipitates (lanes 5 and 6) and $\mathrm{Cbl}$ was not present in Sos precipitates (top, lane 4). The bottom panel of Fig. 8 shows that both antisera immunoprecipitated Grb2, although more Grb2 was present in $\mathrm{Cbl}$ than in Sos immunoprecipitates (lanes 4 to 6). A comparison of antisera raised against the $\mathrm{N}$-terminal, catalytic, and C-terminal regions of Sos showed that all antibodies immunoprecipitated equivalent amounts of Grb2 (results not illustrated). We also tested whether Sos- 1 complexed to $\mathrm{Cbl}$ and Grb2 by comparing the amounts of pp36 and Cbl bound to GST-Grb2 or GST-Sos C-terminal fusion proteins. pp36 is a membrane-bound tyrosine-phosphorylated protein that binds to $\mathrm{Grb} 2 \mathrm{SH} 2$ domains, presumably bringing the Grb2-Sos complex into the proximity of Ras (39). Figure 9 (lanes 5 and 6) confirms that tyrosine-phosphorylated pp36 was bound to Grb2 in an activation-dependent manner. Although the Sos C-terminal fusion protein also bound to tyrosine-phosphorylated pp36 (lanes 3 and 4), Cbl was associated only with the GST-Grb2 fusion protein and not with Sos (top, lanes 3 to 6). These data support the likelihood that Sos-Grb2 and Cbl-Grb2 are present as distinct complexes in T cells.

\section{DISCUSSION}

We show here that upon CD3-CD4 receptor cross-linking in Jurkat cells, a major tyrosine-phosphorylated protein of 115 to

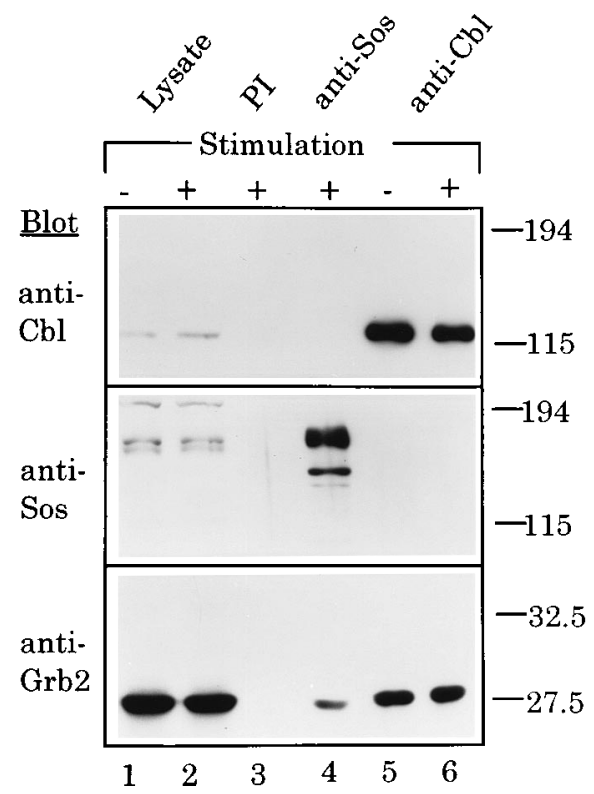

FIG. 8. Cbl binds to Grb2 but not to Sos-1 in intact Jurkat cells. Lysates from $10^{7}$ unstimulated (lanes 1 and 5) or fully activated cells (lanes 2 to 4 and 6) were precleared with normal rabbit serum before addition of normal serum (lane 3 ), Sos-1 antiserum (lane 4), or Cbl antiserum (lanes 5 and 6). Following electrophoresis and transfer to nitrocellulose, samples were probed with anti-Cbl (top), anti-Sos (middle), or anti-Grb2 (bottom) and visualized by chemiluminescence. Lanes 1 and 2 are total-cell lysates from $5 \times 10^{5}$ cells.

$120 \mathrm{kDa}$ binds to Grb2 and p85 and that this protein crossreacts with antisera to the product of the proto-oncogene c-cbl (Fig. 3). Immunoprecipitation with $\mathrm{Cbl}$ antiserum completely removes the $120-\mathrm{kDa}$ band, confirming that the only observable tyrosine-phosphorylated protein in this size range is $\mathrm{Cbl}$ (results not illustrated). Recently, Donovan et al. (9) have reported that GST-Grb2 binds to Cbl stably via the N-terminal but not the C-terminal SH3 domain, and Rivero-Lezcano et al. (33) showed that Nck $\mathrm{SH} 3$ groups bind to $\mathrm{Cbl}$ in vitro. Our

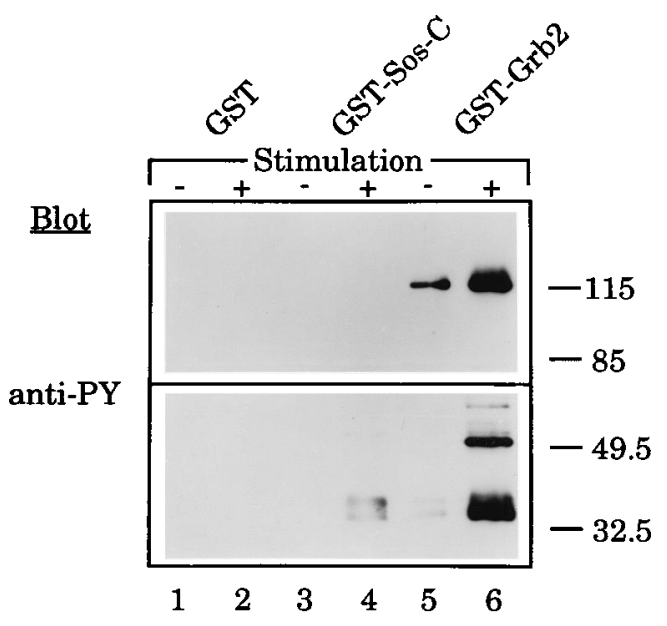

FIG. 9. A C-terminal GST-Sos fusion protein binds pp36 but not $\mathrm{Cbl}$ in activated T cells. Lysates from resting (lanes 1, 3, and 5) or OKT3-OKT4-crosslinked (lanes 2, 4, and 6) cells were bound to $10 \mu \mathrm{g}$ of a GST (lanes 1 and 2), GST-Sos C-terminal (lanes 3 and 4), or GST-Grb2 (lanes 5 and 6) protein, and, after SDS-PAGE with $12 \%$ (bottom) or $7 \%$ (top) polyacrylamide, probed with the antiphosphotyrosine (anti-PY) antibody 4G10. 
data are consistent with these reports in that the GST-R86K mutant of Grb2 lacking the $\mathrm{SH} 2$ domain binds $\mathrm{Cbl}$ with high affinity and capacity in Jurkat cell lysates (Fig. 4). We further show that the ability of $\mathrm{Cbl}$ to bind this mutant GST-Grb2 fusion protein is similar in partially stimulated (OKT3) and fully activated (cross-linked OKT3 plus OKT4) cells. Thus, the $\mathrm{N}$-terminal SH3 domain of Grb2 apparently binds to $\mathrm{Cbl}$ independently of its state of tyrosine phosphorylation, consistent with its predicted binding to one or more of the proline-rich motifs in the $\mathrm{COOH}$ terminus of $\mathrm{Cbl}$.

Our results also show that a mutant Grb2 lacking a functional N-SH3 domain binds little $\mathrm{Cbl}$ in lysates of resting cells or OKT3-stimulated cells but that complete cross-linking of cellular CD3-CD4 receptors markedly enhances Cbl binding to this mutant (Fig. 4). These data may explain the reported binding of a 115 - to $120-\mathrm{kDa}$ tyrosine-phosphorylated protein to GST-Grb2 but not to the SH3 mutant of Grb2 in T cells activated with OKT3 (21). Also consistent with the data presented here are reports that in T cells activated with OKT3, a $120-\mathrm{kDa}$ tyrosine-phosphorylated protein is bound more tightly to Fyn or Lck fusion proteins containing both $\mathrm{SH}$ domains than to the SH3 domain alone $(25,30)$. If, as seems likely, the tyrosine-phosphorylated p120 protein described in these reports is $\mathrm{Cbl}$, the requirement for both $\mathrm{SH} 2$ and $\mathrm{SH} 3$ domains in other adapter molecules such as Nck or Crk may be dependent upon the extent of TCR cross-linking, as well. Our data are consistent with the concept that cross-linking CD3 and CD4 receptors leads to increased tyrosine phosphorylation of one or more sites on $\mathrm{Cb}$ that bind the SH2 domain of Grb2. We have presented evidence by far Western blotting (Fig. 6) and by SDS denaturation (Fig. 5) that the SH2 domain of Grb2 may be directly involved in binding to $\mathrm{Cbl}$. For example, dissociation of preformed complexes by boiling in SDS followed by renaturation has little effect on binding of the SH3-deficient mutant of Grb2 in lysates prepared from fully activated cells. However, the phosphotyrosine motif in peptides recognized by the Grb2 SH2 domain (pY-X-N-Y/Q) $(5,40)$ is not found in any of the tyrosine residues in $\mathrm{Cbl}(7)$. Perhaps increased tyrosine phosphorylation of $\mathrm{Cbl}$ might enhance the affinity of a noncanonical tyrosine-phosphorylated site for the $\mathrm{SH} 2$ domain of Grb2. However, no definitive data showing that the $\mathrm{SH} 2$ domain of Grb2 actually binds to $\mathrm{Cbl}$ in intact cells are yet available. It also cannot be ruled out that the C-terminal SH3 domain, which fails to bind $\mathrm{Cbl}$ (9), can function to some extent as part of intact Grb2.

Grb2 forms a stable complex in vivo with about $50 \%$ of the pool of $\mathrm{Cbl}$ (Fig. 3). In the resting state, $\mathrm{Cbl}$ may also stably associate with other SH3-containing proteins, such as Lck, Fyn, and $\operatorname{Src}(21,25,30,31)$. In a similar manner, Grb2 exists in different intracellular complexes, each complex having a discrete function. It is likely that the SH3-binding proteins dynamin (38) and C3G (42) bind stably to Grb2 and therefore compete with $\mathrm{Cbl}$ for the cellular pool of Grb2. The Ras GTP exchange protein Sos is known to be stably associated with Grb2 through SH3-proline interactions $(10,34)$. The sequence $\mathrm{P}^{494} \mathrm{PVPPPR}$ in $\mathrm{Cbl}$ is identical to a motif in the C-terminus of Sos that binds Grb2 (19) and may serve as a competitive binding site. $\mathrm{Cbl}$ has been reported to be an inhibitor of Sem-5 (Grb2)-Sos binding in Caenorhabditis elegans (35a). Evidence presented here is consistent with the concept that Sos-Grb2 and Cbl-Grb2 form distinct complexes in T cells (Fig. 8 and 9). It is possible that the association of $\mathrm{Cbl}$ or Grb2 with the various $\mathrm{SH} 2-$ or $\mathrm{SH} 3$-containing molecules allows these complexes to be localized in different subcellular fractions.

A prominent consequence of TCR cross-linking is the binding of p 85 to $\mathrm{Cbl}$ and a corresponding increase in associated PI 3-kinase activity (Fig. 3 and 7; Table 1). The small amount of PI 3-kinase activity we have observed in Grb2 immunoprecipitates may represent the fraction of $\mathrm{p} 85$ bound to Grb2 as a trimeric complex, either with $\mathrm{Cbl}$ or with the protein tyrosine kinases Fyn and Lck $(28,43)$, rather than in a direct association. This conclusion is supported by the observation that $\left[{ }^{32} \mathrm{P}\right] \mathrm{GST}-\mathrm{Grb} 2$ binds to $\mathrm{Cbl}$ but not to $\mathrm{p} 85$ in a far Western blot (Fig. 6). However, we have not yet been able to define rigorously whether small amounts of trimeric Grb2-Cbl-PI 3 -kinase complexes actually exist. The sequence $\mathrm{Y}^{739} \mathrm{EAM}$ in Cbl forms a possible recognition site for p85 $\mathrm{SH} 2$ binding, although Shc can also bind to this consensus motif (40). In the IRS-1 signaling complex found in insulin-sensitive cells, binding of p85 SH2 domains to IRS-1 after insulin stimulation increases the associated PI 3-kinase activity 20-fold (3). Exley et al. (11) have shown that the zeta chain of the TCR binds PI 3-kinase and that receptor cross-linking increases the activity nearly threefold. These data suggest that the degree to which PI 3-kinase is activated may depend upon the number of $\mathrm{SH} 2-$ binding motifs that are available for p85 association. IRS-1 contains eight proven sites (23), the TCR zeta chain has two (11), whereas $\mathrm{Cbl}$ apparently has a single site. In addition to SH2 domains, PI 3-kinase can bind to SH3 domains of p56 $6^{\text {lck }}$ and $\mathrm{p} 59^{f y n(\mathrm{~T})}$ in a phosphotyrosine-independent manner via a proline-rich motif on $\mathrm{p} 85$, leading to the generation of phosphoinositide products $(28,43)$. The role of the $\mathrm{N}$-terminal SH3 group of $\mathrm{p} 85$ in forming a stable complex with $\mathrm{Cbl}$ during T-lymphocyte signaling is not known.

A variety of mitogenic and metabolic growth factors activate PI 3-kinase, possibly by causing the p85 subunit to associate with different tyrosine-phosphorylated proteins $(2,18)$. Recent work suggests that the Saccharomyces cerevisiae PI 3-kinase $\mathrm{Vps} 34 \mathrm{p}$ regulates membrane trafficking and protein sorting (14). It has also been demonstrated that PI 3-kinase binding to the platelet-derived growth factor receptor is necessary for trafficking of the activated receptor in the endocytic pathway (16). The homology between the p110 catalytic subunit of mammalian PI 3-kinase and S. cerevisiae Vps34p (14) suggests that the Cbl-PI 3-kinase complex may have a role in protein sorting.

Cbl shows certain structural and biochemical properties similar to those of IRS-1, a $185-\mathrm{kDa}$ protein found in insulinsensitive cells that mediates insulin receptor-PI 3-kinase activation. IRS-1 is a docking protein that is tyrosine phosphorylated by the insulin receptor and binds to $\mathrm{SH} 2$-containing proteins such as Grb2, p85, and the protein tyrosine phosphatase SHPTP2, which in turn stimulate diverse signaling pathways leading to selective mitogenic responses (23). Myeloid progenitor cells also contain a second member of this family, IRS-2, which becomes tyrosine phosphorylated upon insulin and interleukin-4 stimulation and binds PI 3-kinase (44). The sequence of c-Cbl (7) reveals 17 tyrosines, mostly located in the $\mathrm{N}$ terminus, some containing canonical SH2binding motifs. In view of the multiple tyrosine residues and the apparent high stoichiometry of its tyrosine phosphorylation in fully activated $\mathrm{T}$ cells, $\mathrm{Cbl}$ may function as an $\mathrm{SH} 2$ docking protein, allowing the formation of signaling complexes containing different proteins. Evidence suggests that complexes of Cbl with these proteins may be critical in regulating cell growth. For example, overexpression of $\mathrm{Cbl}$ in NIH $3 \mathrm{~T} 3$ cells, while insufficient to induce transformation, nonetheless allows cells to grow to a higher density (6). The demonstration that $\mathrm{v}-c b l$, which is a truncated form of c- $c b l$ encoding a 355-aminoacid N-terminal protein (7), enters the nucleus and is transforming (6), indicates that a naturally cleaved $\mathrm{c}-\mathrm{Cbl}$ protein is found in the nucleus, in a manner similar to the processed form 
of the cytosolic p105 NF-кB precursor (12). To date, efforts to locate such a truncated $\mathrm{c}-\mathrm{Cbl}$ protein in the nucleus have not been successful (1).

Lastly, we wish to point out that the distribution of cell lineages containing proteins that react with $\mathrm{Cbl}$ antibodies is not limited to hematopoietic cells. For example, Cbl was found in HeLa cells (6), and we have observed a 120-kDa tyrosinephosphorylated protein recognized by $\mathrm{Cbl}$ antiserum in activated human kidney cells and mouse 3T3-L1 cells, suggesting that this phosphoprotein may have a general role in signaling.

\section{ACKNOWLEDGMENTS}

This work was supported by Juvenile Diabetes Foundation International Program Project grant 892004 and a Juvenile Diabetes Foundation International Fellowship (to B.R.C.).

We thank Judy Kula for excellent assistance in preparing the manuscript.

\section{REFERENCES}

1. Andoniou, C., C. Thien, and W. Langdon. 1994. Tumour induction by activated $a b l$ involves tyrosine phosphorylation of the product of the $c b l$ oncogene. EMBO J. 13:4515-4523.

2. Auger, K., L. Serunian, S. Soltoff, P. Lippy, and L. Cantley. 1989. PDGFdependent tyrosine phosphorylation stimulates production of novel polyphosphoinositides in intact cells. Cell 57:167-175.

3. Backer, J., M. Myers, S. Shoelson, D. Chin, K.-J. Sun, M. Miralpeix, P. Hu, B. Margolis, E. Skolnik, J. Schlessinger, and M. White. 1992. Phosphatidylinositol $3^{\prime}$-kinase is activated by association with IRS-1 during insulin stimulation. EMBO J. 11:3469-3479.

4. Baltensperger, K., L. Kozma, A. Cherniack, J. Klarlund, A. Chawla, U. Banerjee, and M. P. Czech. 1993. Binding of the Ras activator son of Sevenless to insulin receptor substrate-1 signaling complexes. Science 260: 1950-1952.

5. Batzer, A. G., D. Rotin, J. M. Ureña, E. Y. Skolnik, and J. Schlessinger. 1994 Hierarchy of binding sites for Grb2 and Shc on the epidermal growth factor receptor. Mol. Cell. Biol. 14:5192-5201.

6. Blake, T., K. Heath, and W. Langdon. 1993. The truncation that generated the v-cbl oncogene reveals an ability for nuclear transport, DNA binding and acute transformation. EMBO J. 12:2017-2026.

7. Blake, T., M. Shapiro, H. Morse, and W. Langdon. 1991. The sequences of the human and mouse c-cbl proto-oncogenes show v-cbl was generated by a large truncation encompassing a proline-rich domain and a leucine zipperlike motif. Oncogene 6:653-657.

8. Couture, C., G. Baier, A. Altman, and T. Mustelin. 1994. p56 $6^{\mathrm{lck}}-$ independent activation and tyrosine phosphorylation of $\mathrm{p} 72^{\mathrm{syk}}$ by T-cell antigen receptor/ CD3 stimulation. Proc. Natl. Acad. Sci. USA 91:5301-5305.

9. Donovan, J., R. Wange, W. Langdon, and L. Samelson. 1994. The protein product of the c-cbl protooncogene is the $120-\mathrm{kDa}$ tyrosine-phosphorylated protein in Jurkat cells activated via the T cell antigen receptor. J. Biol. Chem. 169:22921-22924.

10. Egan, S., B. Giddings, M. Brooks, L. Buday, A. Sizeland, and R. Weinberg. 1993. Association of Sos Ras exchange protein with Grb2 is implicated in tyrosine kinase signal transduction and transformation. Nature (London) 363:45-51.

11. Exley, M., L. Varticovski, M. Peter, J. Sancho, and C. Terhorst. 1994. Association of phosphatidylinositol 3-kinase with a specific sequence of the $\mathrm{T}$ cell receptor zeta chain is dependent on T cell activation. J. Biol. Chem. 269:15140-15146.

12. Ghosh, S., A. Gifford, L. Riviere, P. Tempst, G. Nolan, and D. Baltimore. 1990. Cloning of the p50 DNA binding subunit of NF-kB: homology to rel and dorsal. Cell 62:1019-1029.

13. Harlow, E., and E. Lane. 1988. Antibodies: a laboratory manual. Cold Spring Harbor Laboratory Press, Cold Spring Harbor, N.Y.

14. Herman, P. K., and S. D. Emr. 1990. Characterization of VPS34, a gene required for vacuolar protein sorting and vacuole segregation in Saccharomyces cerevisiae. Mol. Cell. Biol. 10:6742-6754.

15. Howe, L., and A. Weiss. 1995. Multiple kinases mediate T-cell-receptor signaling. Trends Biochem. Sci. 20:59-65.

16. Joly, M., A. Kazlauskas, F. Fay, and S. Corvera. 1994. Disruption of PDGF receptor trafficking by mutation of its PI-3 kinase binding sites. Science 263:684-687.

17. June, C., M. Fletcher, J. Ledbetter, and L. Samelson. 1990. Increases in tyrosine phosphorylation are detectable before phospholipase $\mathrm{C}$ activation after T cell receptor stimulation. J. Immunol. 144:1591-1599.

18. Kapeller, R., and L. Cantley. 1994. Phosphatidylinositol 3-kinase. Bioessays 16:565-576.
19. Li, N., A. Batzer, R. Daly, V. Yajnik, E. Skolnik, P. Chardin, D. Bar-Sagi, B. Margolis, and J. Schlessinger. 1993. Guanine-nucleotide-releasing factor hSos1 binds to Grb2 and links receptor tyrosine kinases to Ras signalling. Nature (London) 363:85-88.

20. Mayer, B., and D. Baltimore. 1993. Signaling through SH2 and SH3 domains Trends Cell Biol. 3:8-13.

21. Motto, D., S. Ross, J. Jackman, Q. Sun, A. Olson, P. Findell, and G. Koretzky. 1994. In vivo association of GRB2 with pp116, a substrate of the $\mathrm{T}$ cell antigen receptor-activated protein tyrosine kinase. J. Biol. Chem. 269:21608-21613.

22. Mustelin, T., and P. Burn. 1993. Regulation of $s r c$ family tyrosine kinases in lymphocytes. Trends Biochem. Sci. 18:215-220.

23. Myers, M., X.-J. Sun, and M. White. 1994. The IRS-1 signaling system. Trends Biochem. Sci. 19:289-293.

24. Ninomiya, N., K. Hazeki, Y. Fukui, T. Seya, T. Okada, O. Hazeki, and M. Ui. 1994. Involvement of phosphatidylinositol 3-kinase in Fc gamma receptor signaling. J. Biol. Chem. 269:22732-22737.

25. Panchamoorthy, G., T. Fukazawa, L. Stolz, G. Payne, K. Reedquist, S. Shoelson, Z. Songyang, L. Cantley, C. Walsh, and H. Band. 1994. Physical and functional interactions between $\mathrm{SH} 2$ and $\mathrm{SH} 3$ domains of the Src family protein tyrosine kinase p59 $9^{f y n}$. Mol. Cell. Biol. 14:6372-6385.

26. Pawson, T., and G. Gish. 1992. SH 2 and SH3 domains: from structure to function. Cell 71:359-362.

27. Pelicci, G., L. Lanfrancone, F. Grignani, J. McGlade, F. Cavallo, G. Forni, I. Nicoletti, F. Grignani, T. Pawson, and P. Pelicci. 1992. A novel transforming protein (SHC) with an $\mathrm{SH} 2$ domain is implicated in mitogenic signal transduction. Cell 70:93-104.

28. Prasad, K., O. Janssen, R. Kapeller, M. Raab, L. Cantley, and C. Rudd. 1993. Src-homology 3 domain of protein kinase $\mathrm{p} 59^{\mathrm{fyn}}$ mediates binding to phosphatidylinositol 3-kinase in T cells. Proc. Natl. Acad. Sci. USA 90:73667370.

29. Ravichandran, K., K. Lee, Z. Songyang, L. Cantley, P. Burn, and S. Burakoff. 1993. SHC interacts with the zeta chain of the T cell receptor upon T cell activation. Science 262:902-904.

30. Reedquist, K., T. Fukazawa, B. Druker, G. Panchamoorthy, S. Shoelson, and H. Band. 1994. Rapid T-cell receptor-mediated tyrosine phosphorylation of p120, an Fyn/Lck Src homology 3 domain-binding protein. Proc. Natl. Acad. Sci. USA 91:4135-4139.

31. Reif, K., L. Buday, J. Downward, and D. Cantrell. 1994. SH3 domains of the adapter molecule Grb2 complex with two proteins in T cells: the guanine nucleotide exchange protein Sos and a $75-\mathrm{kDa}$ protein that is a substrate for $\mathrm{T}$ cell antigen receptor-activated tyrosine kinases. J. Biol. Chem. 269:1408114087.

32. Reth, M. 1989. Antigen receptor tail clue. Nature (London) 338:383-384.

33. Rivero-Lezcano, O., J. Sameshima, A. Marcilla, and K. Robbins. 1994. Physical association between src homology 3 elements and the protein product of the c-cbl proto-oncogene. J. Biol. Chem. 269:17363-17366.

34. Rozakis-Adcock, M., J. McGlade, G. Mbamalu, G. Pelicci, R. Daly, W. Li, A. Batzer, S. Thomas, J. Brugge, P. Pelicci, J. Schlessinger, and T. Pawson. 1992. Association of the Shc and Grb2/Sem 5 SH2-containing proteins is implicated in activation of the Ras pathway by tyrosine kinases. Nature (London) 360:689-692.

35. Rudd, C., O. Janssen, Y.-C. Cai, A. Silva, M. Raab, and K. Prasad. 1994 Two-step TCR zeta/CD3-CD4 and CD28 signaling in T cells: SH2/SH3 domains, protein-tyrosine and lipid kinases. Immunol. Today 15:225-234.

35a.Samelson, L. Personal communication.

36. Samelson, L., A. Phillips, E. Luong, and R. Klausner. 1990. Association of the fyn protein-tyrosine kinase with the T cell antigen receptor. Proc. Natl. Acad. Sci. USA 87:4358-4363.

37. Samelson, L. E., and R. D. Klausner. 1992. Tyrosine kinases and tyrosinebased activation motifs. Current research on activation via the $\mathrm{T}$ cell antigen receptor. J. Biol. Chem. 267:24913-24916.

38. Seedorf, K., G. Kosta, R. Lammers, P. Bashkin, R. Daly, W. Burgess, A. van der Bliek, J. Schlessinger, and A. Ullrich. 1994. Dynamin binds to SH3 domains of phospholipase C $\gamma$ and Grb-2. J. Biol. Chem. 269:16009-16014.

39. Sieh, M., A. Batzer, J. Schlessinger, and A. Weiss. 1994. GRB2 and phospholipase C- $\gamma 1$ associate with a 36 - to 38 -kilodalton phosphotyrosine protein after T-cell receptor stimulation. Mol. Cell. Biol. 14:4435-4442.

40. Songyang, Z., S. E. Shoelson, J. McGlade, P. Olivier, T. Pawson, X. R. Bustelo, M. Barbacid, H. Sabe, H. Hanafusa, T. Yi, R. Ren, D. Baltimore, S. Ratnofsky, R. A. Feldman, and L. C. Cantley. 1994. Specific motifs recognized by the SH2 domains of Csk, 3BP2, fps/fes, Grb2, HCP, SHC, Syk, and Vav. Mol. Cell. Biol. 14:2777-2785.

41. Straus, D., and A. Weiss. 1993. The CD3 chain of the T cell antigen receptor associates with the ZAP-70 tyrosine kinase and is tyrosine phosphorylated after receptor stimulation. J. Exp. Med. 178:1523-1530.

42. Tanaka, S., T. Morishita, Y. Hashimoto, S. Hattori, S. Nakamura, M. Shibuya, K. Matuoka, T. Takenawa, T. Kurata, K. Nagashima, and M. Matsuda. 1994. C3G, a guanine nucleotide-releasing protein expressed ubiquitously, binds to the Src homology 3 domains of CRK and GRB2/ASH proteins. Proc. Natl. Acad. Sci. USA 91:3443-3447. 
43. Vogel, L. B., and D. J. Fujita. 1993. The SH3 domain of p56 $6^{\text {lck }}$ is involved in binding to phosphatidylinositol 3'-kinase from T lymphocytes. Mol. Cell. Biol. 13:7408-7417.

44. Wang, L.-M., A. Keegan, L. Weiqun, G. Lienhard, S. Pacini, J. Gutkind, M. Myers, Jr., X.-J. Sun, M. White, S. Aaronson, W. Paul, and J. Pierce. 1993. Common elements in interleukin 4 and insulin signaling pathways in factordependent hematopoietic cells. Proc. Natl. Acad. Sci. USA 90:4032-4036.
45. Ward, S., S. Ley, C. MacPhee, and D. Cantrell. 1992. Regulation of D-3 phosphoinositides during $\mathrm{T}$ cell activation via the $\mathrm{T}$ cell antigen receptor/ CD3 complex and CD2 antigens. Eur. J. Immunol. 22:45-49.

46. Weiss, A., and J. Imboden. 1987. Cell surface molecules and early events involved in human T lymphocyte activation. Adv. Immunol. 41:1-38.

47. Weiss, A., and D. Littman. 1994. Signal transduction by lymphocyte antigen receptors. Cell 7:263-274. 